\title{
Effects of antibacterial mineral leachates on the cellular ultrastructure, morphology, and membrane integrity of Escherichia coli and methicillin-resistant Staphylococcus aureus
}

Caitlin C Otto ${ }^{1,2}$, Tanya M Cunningham ${ }^{1,2}$, Michael R Hansen², Shelley E Haydel ${ }^{1,2^{*}}$

\begin{abstract}
Background: We have previously identified two mineral mixtures, CB07 and BY07, and their respective aqueous leachates that exhibit in vitro antibacterial activity against a broad spectrum of pathogens. The present study assesses cellular ultrastructure and membrane integrity of methicillin-resistant Staphylococcus aureus (MRSA) and Escherichia coli after exposure to CB07 and BY07 aqueous leachates.
\end{abstract}

Methods: We used scanning and transmission electron microscopy to evaluate E. coli and MRSA ultrastructure and morphology following exposure to antibacterial leachates. Additionally, we employed Baclight LIVE/DEAD staining and flow cytometry to investigate the cellular membrane as a possible target for antibacterial activity.

Results: Scanning electron microscopy (SEM) and transmission electron microscopy (TEM) imaging of E. coli and MRSA revealed intact cells following exposure to antibacterial mineral leachates. TEM images of MRSA showed disruption of the cytoplasmic contents, distorted cell shape, irregular membranes, and distorted septa of dividing cells. TEM images of $E$. coli exposed to leachates exhibited different patterns of cytoplasmic condensation with respect to the controls and no apparent change in cell envelope structure. Although bactericidal activity of the leachates occurs more rapidly in E. coli than in MRSA, LIVE/DEAD staining demonstrated that the membrane of $E$. coli remains intact, while the MRSA membrane is permeabilized following exposure to the leachates.

Conclusions: These data suggest that the leachate antibacterial mechanism of action differs for Gram-positive and Gram-negative organisms. Upon antibacterial mineral leachate exposure, structural integrity is retained, however, compromised membrane integrity accounts for bactericidal activity in Gram-positive, but not in Gram-negative cells.

\section{Background}

With the advent of antibiotics in the early $20^{\text {th }}$ century, morbidity and mortality from bacterial infections were dramatically reduced in the industrialized world. In recent decades, these advances have been tempered by the rapid, widespread emergence of microorganisms that are resistant to multiple, commonly used antibiotics [1]. As our arsenal of effective antibiotics is diminishing, the pursuit of novel therapeutic agents is becoming progressively more urgent.

* Correspondence: Shelley.Haydel@asu.edu

'School of Life Sciences, Arizona State University, Tempe, AZ, USA

Full list of author information is available at the end of the article
Minerals have been utilized in traditional medicine for centuries as topical treatments for cutaneous wounds, digestive treatments for gastrointestinal ailments, nutritional supplements, and for removal of toxins from the body [2-4]. Traditionally, the mechanism of mineralbased healing activities has been attributed to physical properties, such as the expansive surface area and resulting highly adsorptive properties of clays present in the mixtures [2].

Recently, various mineral products marketed for their health benefits have been investigated for their potential antimicrobial properties [5-8]. However, only a small number of clay products have been shown to be 
antibacterial and the mechanism of antibacterial activity has been elucidated for very few of these products [8]. Falkinham et al. [8] attributed the antibacterial effects of Jordan's red soils to bacteriocins produced by bacteria present in the clays. It was hypothesized that application of the red soil to an infected area of the skin allowed the inherent organisms to proliferate, produce bacteriocins, and thus kill the infectious pathogens [8]. Mpuchane et al. [7,9] tested a total of 102 clays from South Africa and determined that only nine of these clay samples had antibacterial activity. The antibacterial properties of these South African medicinal clays were attributed to the low $\mathrm{pH}$ environment of the hydrated mineral suspensions $(\mathrm{pH}<4)$, and it was further postulated that metal cations could contribute to toxicity [7,9]. While Mpuchane et al. [9] determined that nine clays had antibacterial properties, none of the clays specifically sold for use against bacterial infections had antibacterial activity. Therefore, it is essential to scientifically validate the efficacy of these mineral products prior to use in a clinical setting.

Clay minerals are excellent adsorbent materials due to their small particle size $(<2 \mu \mathrm{m})$, stable layered structure, and high cation exchange capacity [10]. In a pHdependent manner, exchangeable cations can bind to the clay surface, balancing the negative charge of the clay structure. In hydrated suspensions, the adsorbate can then be released into the aqueous solution, varying the cationic composition of the solution $[10,11]$. These released metal ions are known to have toxic effects on bacteria by competing with essential enzyme cofactors, irreversibly binding biological molecules to inhibit function, replacing ions essential to membrane stabilization, and inducing DNA mutations [12-15]. For example, metal cations, such as iron, copper, and chromium, have been implicated in production of elevated levels of reactive oxygen species which can lead to DNA damage, lipid peroxidation, protein oxidation, and eventual cell death [16-18]. Metal ion toxicity varies with $\mathrm{pH}$ and appears to be related to changes in ion species that occur as the $\mathrm{pH}$ is adjusted $[12,15,19]$. These alterations in toxicity are due to the relative abilities of the ion species to bind cell surfaces and exert their effects [12].

In a prior study, we identified two mineral mixtures, arbitrarily designated BY07 and CB07, that exhibit antibacterial activity [5]. From these mineral mixtures, we prepared aqueous leachates that contain metal ions released from the clay minerals, but are absent of all solid particles. These leachates retain antibacterial activity, establishing that the mechanism of action is dependent on chemical, not physical interactions [5]. Further investigations revealed that the antibacterial activity of BY07 and CB07 mineral mixtures is related to the pHdependent bioavailability of toxic metal ions in a low
$\mathrm{pH}$ environment [5]. While we have discovered that $\mathrm{pH}$-dependent ion toxicity mediates $\mathrm{CB} 07$ and BY07 antibacterial activity, further investigations must be performed to fully understand the precise mechanism of action. In this study, we assessed whether cell lysis occurs in E. coli and MRSA cells during leachate exposure and investigated cellular membrane integrity as possible mechanisms of action of the aqueous leachates.

\section{Methods}

\section{Bacterial strains and growth conditions}

E. coli ATCC 25922, obtained from the American Type Culture Collection, and MRSA, obtained from Sonora Quest Laboratories (Tempe, AZ, USA), were used for all studies as previously described [6]. E. coli was grown on Luria-Bertani (LB) agar or in LB broth, and MRSA was grown on trypticase soy agar (TSA) or in trypticase soy broth (TSB). Both bacterial strains were grown at $37^{\circ} \mathrm{C}$ with gentle rotary mixing.

\section{Mineral leachate preparation}

Mineralogical and major chemical characterization of the CB07 and BY07 mineral mixtures has been previously described [5]. Briefly, the CB07 mineral is primarily composed of quartz (45.5\%), illite (19.8\%), and calcium smectite $(17.2 \%)$, while the BY07 mineral primarily consists of calcium smectite (37.3\%), anorthoclase feldspar (23.0\%), and quartz (13.7\%) [5]. Major oxide chemical analyses reveal that $\mathrm{CB} 07$ and BY07 are primarily composed of silicon, aluminum, iron, calcium, sodium, potassium, and sulfur [5]. Leachates of CB07 and BY07 mineral samples were prepared as previously described [5]. Briefly, $1 \mathrm{~g}$ of autoclaved minerals was vigorously agitated in $20 \mathrm{~mL}$ of UV-irradiated, ultrapure, deionized $\mathrm{H}_{2} \mathrm{O}\left(\mathrm{dH}_{2} \mathrm{O}\right)$ for $18-24$ hours at room temperature. The suspension was centrifuged at $31,000 \times \mathrm{g}$ for $3 \mathrm{~h}$ to remove the remaining insoluble minerals and then sterilized by passage through a $0.22 \mu \mathrm{m}$ filter.

\section{Antibacterial susceptibility testing of mineral leachates}

E. coli and MRSA exponential phase cultures were prepared by diluting overnight cultures into fresh growth medium to a concentration of $10^{7} \mathrm{CFU} / \mathrm{mL}$ and continuing growth at $37^{\circ} \mathrm{C}$ with gentle rotary mixing until the cultures reached mid-logarithmic phase of growth. Bacterial cells were collected by centrifugation, washed once in phosphate-buffered saline (PBS), and suspended in the appropriate leachate solution or sterile $\mathrm{dH}_{2} \mathrm{O}$ at an initial concentration of $10^{7} \mathrm{CFU} / \mathrm{mL}$. Initial $\mathrm{CFU}$ concentrations were confirmed by plating the control bacterial population and enumerating colonies after $24 \mathrm{~h}$ incubation at $37^{\circ} \mathrm{C}$. Due to experimental sample processing, the $0 \mathrm{~h}$ experimental exposure times were $\sim 3 \mathrm{~min}$. Experimental samples were incubated at $37^{\circ} \mathrm{C}$ 
with gentle rotary mixing for a specified time, and cell survival was determined by plating duplicate 10 -fold serial dilutions for each sample at appropriate time points and enumerating colonies after $24 \mathrm{~h}$ incubation at $37^{\circ} \mathrm{C}$.

\section{Scanning electron microscopy (SEM)}

Bacterial cells were prepared for SEM as described above, with the exceptions that cultures were collected at late logarithmic phase of growth and initial concentrations were $10^{8} \mathrm{CFU} / \mathrm{ml}$. Following $24 \mathrm{~h}$ exposure to the leachates, washed cells were inoculated onto a poly-L-lysine-coated coverglass slide and allowed to adhere for $5 \mathrm{~min}$ at room temperature. After washing the slide in $50 \mathrm{mM}$ sodium phosphate buffer, $\mathrm{pH} 7$, the cells were chemically crosslinked onto the slide in $2 \%$ gluteraldehyde (buffered in $50 \mathrm{mM}$ sodium phosphate, $\mathrm{pH} 7$ ). The immobilized cells were then fixed in $2 \%$ osmium tetroxide for $15 \mathrm{~min}$ at room temperature, washed three times in $50 \mathrm{mM}$ sodium phosphate buffer, and dehydrated in 5 min washes in a sequential acetone series $(20 \%, 40 \%, 60 \%, 80 \%, 3 \times 100 \%)$. The samples were critical point dried in a Balzers 020 critical point dryer, attached to aluminum mounting stubs, sputter coated with gold-palladium, and imaged with an XL30 Environmental SEM equipped with a field emission gun. A minimum of 200 cells was counted from each of three independent replicates.

\section{Transmission electron microscopy (TEM)}

E. coli and MRSA exponential phase cultures were prepared as described above for SEM with an initial concentration of $10^{8} \mathrm{CFU} / \mathrm{mL}$. Following $24 \mathrm{~h}$ exposure to the leachates, cells were fixed in $2 \%$ gluteraldehyde buffered in $50 \mathrm{mM}$ phosphate, $\mathrm{pH} 7$, for $2 \mathrm{~h}$ at room temperature. The cells were then washed in $50 \mathrm{mM}$ phosphate and resuspended in $1 \%$ agarose (final concentration). The agarose-embedded cell pellets were fixed in $2 \%$ osmium tetroxide (buffered in $50 \mathrm{mM}$ phosphate) for $2 \mathrm{~h}$ at room temperature, washed three times in 50 $\mathrm{mM}$ phosphate buffer, washed three times in $\mathrm{dH}_{2} \mathrm{O}$, and en bloc stained in $0.5 \%$ uranyl acetate overnight at $4^{\circ} \mathrm{C}$. The pellets were dehydrated in 10 min washes with a sequential acetone series $(20 \%, 40 \%, 60 \%, 80 \%, 3 \times 100 \%)$ and infiltrated with Spurr's resin. Thin sections $(70 \mathrm{~nm})$ were cut using an Ultracut $\mathrm{R}$ ultramicrotome (Leica Microsystems, Vienna, Austria). Sections were captured on formvar-coated, 300-mesh copper grids, post-stained in uranyl acetate and Sato's lead citrate, and observed on a Philips CM12 TEM at $80 \mathrm{kV}$. A minimum of 60 cells was counted from each of three independent replicates.

\section{Flow cytometric measurements}

To evaluate the membrane integrity of $E$. coli and MRSA following exposure to the leachates, the BacLight LIVE/DEAD membrane permeability kit (Invitrogen, Carlsbad, CA, USA) was used following the manufacturer guidelines. E. coli and MRSA mid-logartithmic phase cultures were prepared as described above and harvested at an initial concentration of $10^{8} \mathrm{CFU} / \mathrm{mL}$. A standard curve was prepared by mixing live $(0.85 \%$ saline-exposed) cells and dead (40\% isopropanolexposed) cells together at various proportions of live: dead cells (100\%, 75\%, 50\%, 25\%, 0\% alive). Following exposure to the leachates or control conditions, cells were incubated in $5 \mu \mathrm{M}$ SYTO9 and $30 \mu \mathrm{M}$ propidium iodide (PI) for $15 \mathrm{~min}$ in the dark and then immediately subjected to flow cytometric analysis. E. coli cells were analyzed following $1 \mathrm{~h}$ exposure to CB07 leachate (CB07-L) and $6 \mathrm{~h}$ exposure to BY07 leachate (BY07-L), while MRSA cells were analyzed following $15 \mathrm{~h}$ exposure to either CB07-L or BY07-L. These time points represent the exposure time required for bactericidal activity ( $\geq 99.9 \%$ killing) of the different leachates against the two cell types. A Cytomics FC 500 flow cytometer (Beckman Coulter, Inc., Brea, CA, USA) fitted with a $488 \mathrm{~nm}$ excitation laser was used for membrane permeability analyses. Green fluorescence was detected on channel FL1 with a $525 \mathrm{~nm}$ bandpass filter. Red fluorescence was detected on channel FL3 with a 620 bandpass filter. Since the SYTO9 dye emits a strong signal at a wavelength of $600 \mathrm{~nm}$, it overlaps with the PI emission [20]. Therefore, membrane permeabilization is determined by a horizontal population shift that occurs down the green fluorescent intensity axis. For each series of flow cytometric measurements, 50,000 cells were counted and analyzed.

\section{Results}

\section{Antibacterial mineral leachates}

The effects of BY07-L and CB07-L on the growth of E. coli and MRSA were investigated by performing in vitro antimicrobial susceptibility experiments. Bacteria, at initial concentrations of $10^{7} \mathrm{CFU} / \mathrm{mL}$, were incubated in BY07-L or CB07-L for $24 \mathrm{~h}$ prior to plating to determine viability. Due to variable bactericidal activity of the leachates, it is essential to regularly test the antibacterial activity of the leachates. For example, we previously demonstrated that E. coli is completely killed by BY07-L after $18 \mathrm{~h} \mathrm{[5].}$ However, in the present study, exposure to BY07-L completely killed $E$. coli after a $3 \mathrm{~h}$ incubation (Figure 1a). E. coli viability was completely eliminated following $24 \mathrm{~h}$ exposure to both mineral leachates (Figure 1a). At the $0 \mathrm{~h}$ time point, leachate-exposed E. coli and MRSA cell 


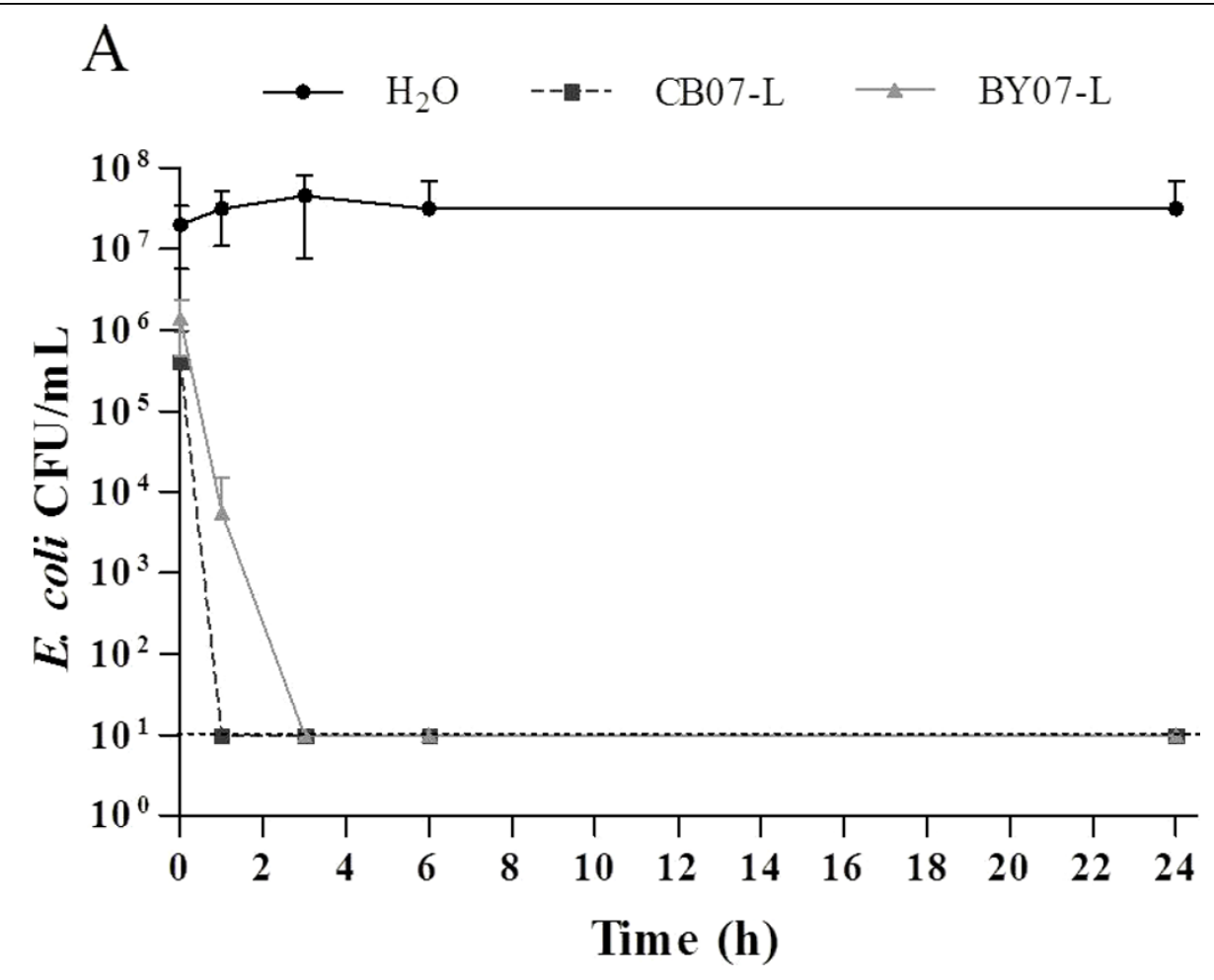

B
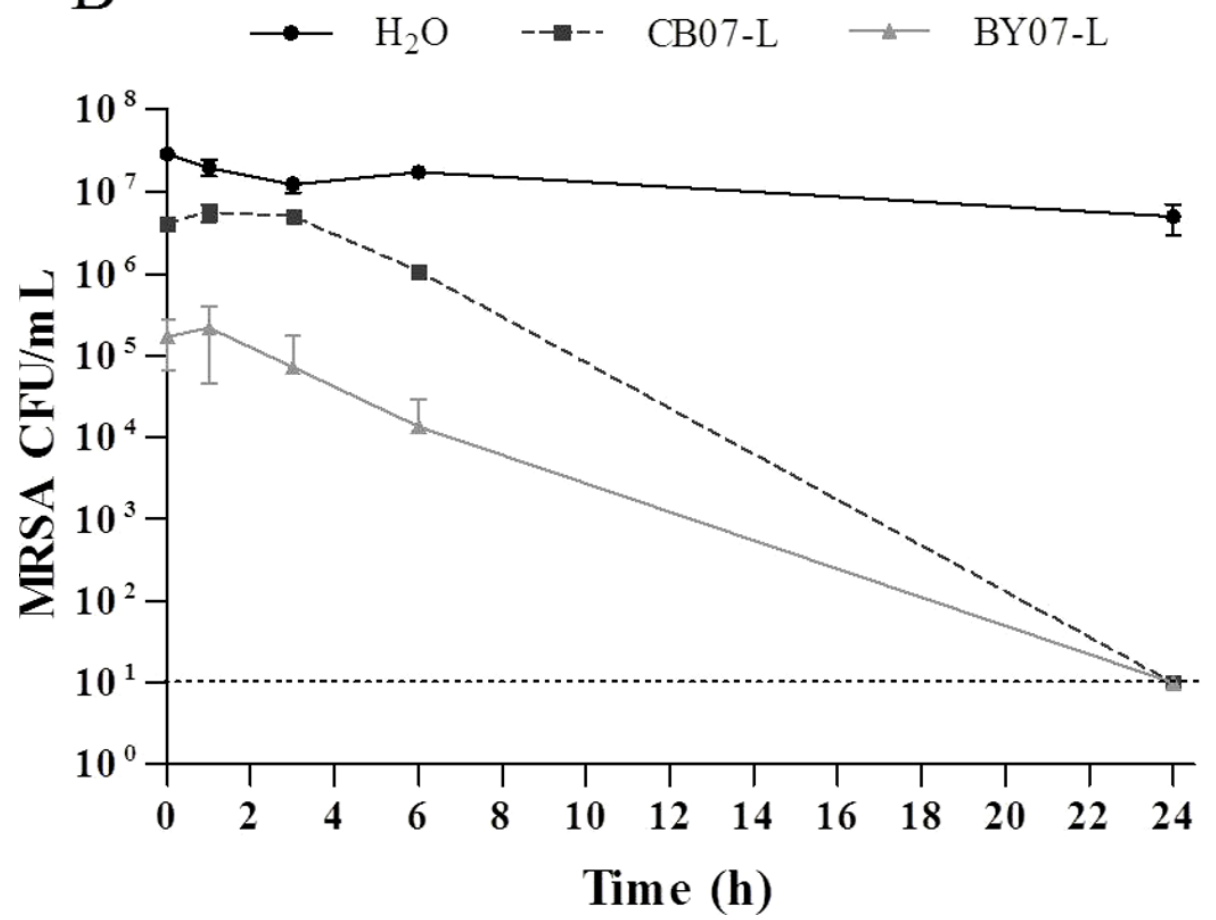

Figure 1 E. coli (a) and MRSA (b) survival in CB07 and BY07 mineral leachates for $\mathbf{2 4} \mathbf{h}$. Values represent the mean CFU and SD of at least three independent experiments. The dotted line represents the limit of CFU detection. 
viability was consistently $1-\log _{10}$ unit lower than the respective $\mathrm{dH}_{2} \mathrm{O}$ controls (Figure 1). Experimental processing, requiring approximately $3 \mathrm{~min}$ to complete, accounted for the initial decrease in cell viability and also demonstrated the rapid bactericidal activity of the two leachates. With respect to the $6 \mathrm{~h}$ water control, MRSA exposure to $\mathrm{CB} 07-\mathrm{L}$ resulted in a $>1-\log _{10}$ unit reduction in viability after $6 \mathrm{~h}$ (Figure 1b). Alternatively, exposure to BY07-L for 6 h resulted in bactericidal activity (Figure 1b). In both cases, MRSA viability was completely eliminated after $24 \mathrm{~h}$ (Figure 1b).

\section{Scanning electron microscopy}

SEM and TEM were used to directly observe morphological and ultrastructural changes induced in E. coli and MRSA upon exposure to and killing by the BY07 and CB07 antibacterial leachates. As shown in Figure 1a, E. coli was completely killed after $24 \mathrm{~h}$ exposure to BY07-L and CB07-L. SEM images of E. coli showed that the cells did not lyse following exposure to the leachates (Figures $2 \mathrm{~g}$ and $2 \mathrm{i}$ ). Enumeration of imaged cells revealed that $>99.0 \%$ of leachate-exposed cells remain intact and that damaged or lysed cells were only observed in $<1 \%$ of CB07-L- and BY07-L-exposed cells (Figure 3a). SEM images of $E$. coli cells grown in LB broth showed a rough cell surface with discrete ridges (Figure 2a). Leachate-treated (Figures $2 \mathrm{~g}$ and $2 \mathrm{i}$ ) E. coli cells also exhibited a rough cell surface with discrete ridges, while water-incubated (Figure 2c) and low $\mathrm{pH}$ buffer-treated (Figure 2e) E. coli cells had a wavy and smooth cell surface appearance. Further, 30.7\% of CB07L-treated cells exhibited the appearance of membrane bleb-like structures or deposits, while $12.9 \%$ of BY07-Ltreated cells had apparent blebs or deposits on the cell surface (Figure 3a). Overall, both CB07-L- and BY07-Ltreated $E$. coli cells maintained their rod shape with very few distorted cells (Figure 3a).

As shown in Figure 1b, MRSA was completely killed after $24 \mathrm{~h}$ exposure to the leachates. SEM images of MRSA demonstrated intact cells following exposure to CB07-L and BY07-L (Figures $2 \mathrm{~h}$ and $2 \mathrm{j}$ ), with damaged or lysed cells observed in $2.5 \%$ and $6.8 \%$ of cells, respectively (Figure 3b). MRSA cells incubated in water for 24 $\mathrm{h}$ showed flattened and distorted cells with bleb-like structures or deposits (Figure 2d), while cells in broth and low pH buffer exhibited a smooth cell surface appearance (Figures $2 \mathrm{~b}$ and $2 \mathrm{f}$ ). In contrast, following exposure to the leachates, the MRSA cell surface appeared rough, showed the appearance of bleb-like structures, and had an increased abundance of extracellular debris (Figures $2 \mathrm{~h}$ and 2j). Further, 95.4\% and 94.5\%, respectively, of CB07-L- and BY07-L-treated cells exhibited bleb-like structures, while only $11.1 \%$ of cells grown in TSB showed blebs (Figure $3 b$ ).

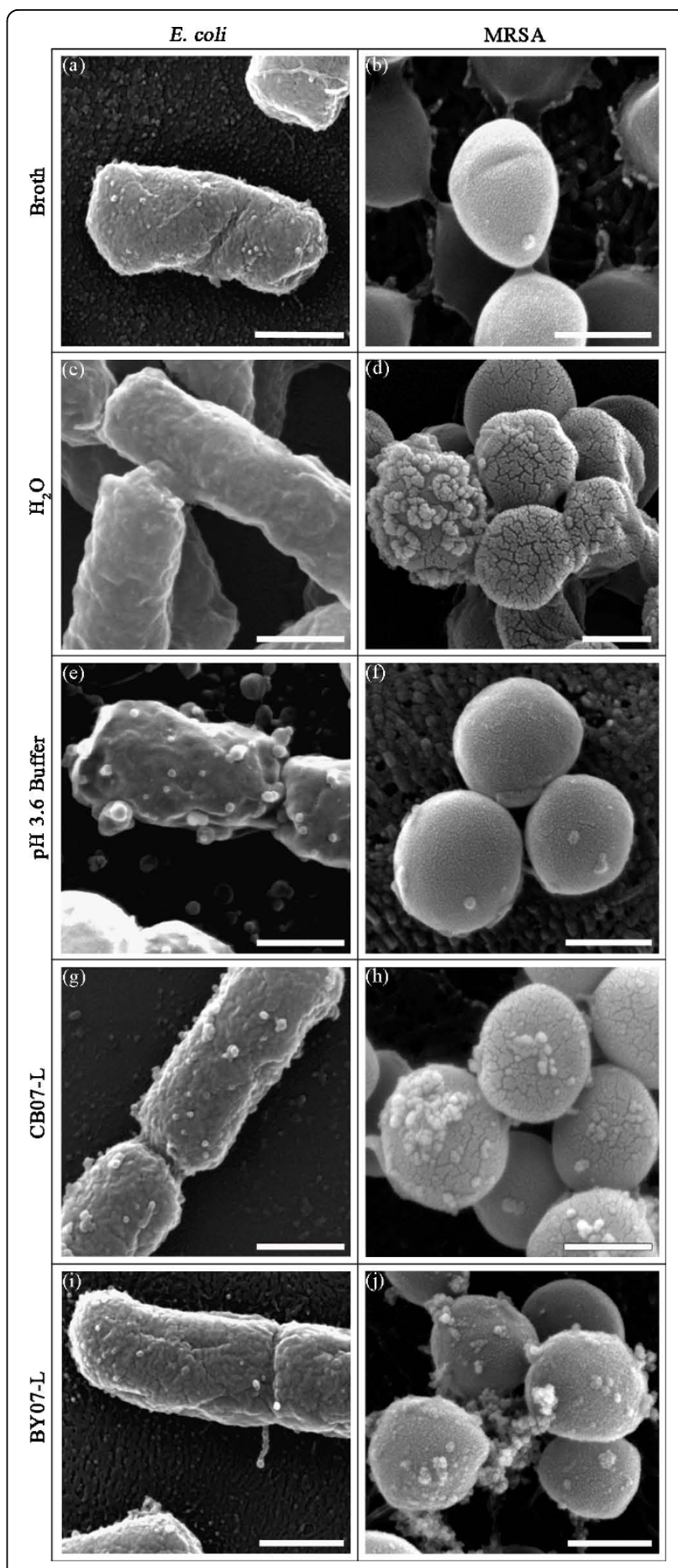

Figure 2 SEM images of $E$. coli $(a, c, e, g, i)$ and MRSA (b, d, f, $h, j)$ after 24 h incubation in broth, $\mathrm{dH}_{2} \mathrm{O}, \mathrm{pH} 3.6$ buffer, CB07L, or BY07-L. Scale bar $=500 \mathrm{~nm}$.

\section{Transmission electron microscopy}

TEM images of E. coli further confirmed that the cells remain intact following exposure to the leachates (Figures 4g,i, and 5a), indicating that cell lysis is not the antibacterial mechanism of action. TEM images of 


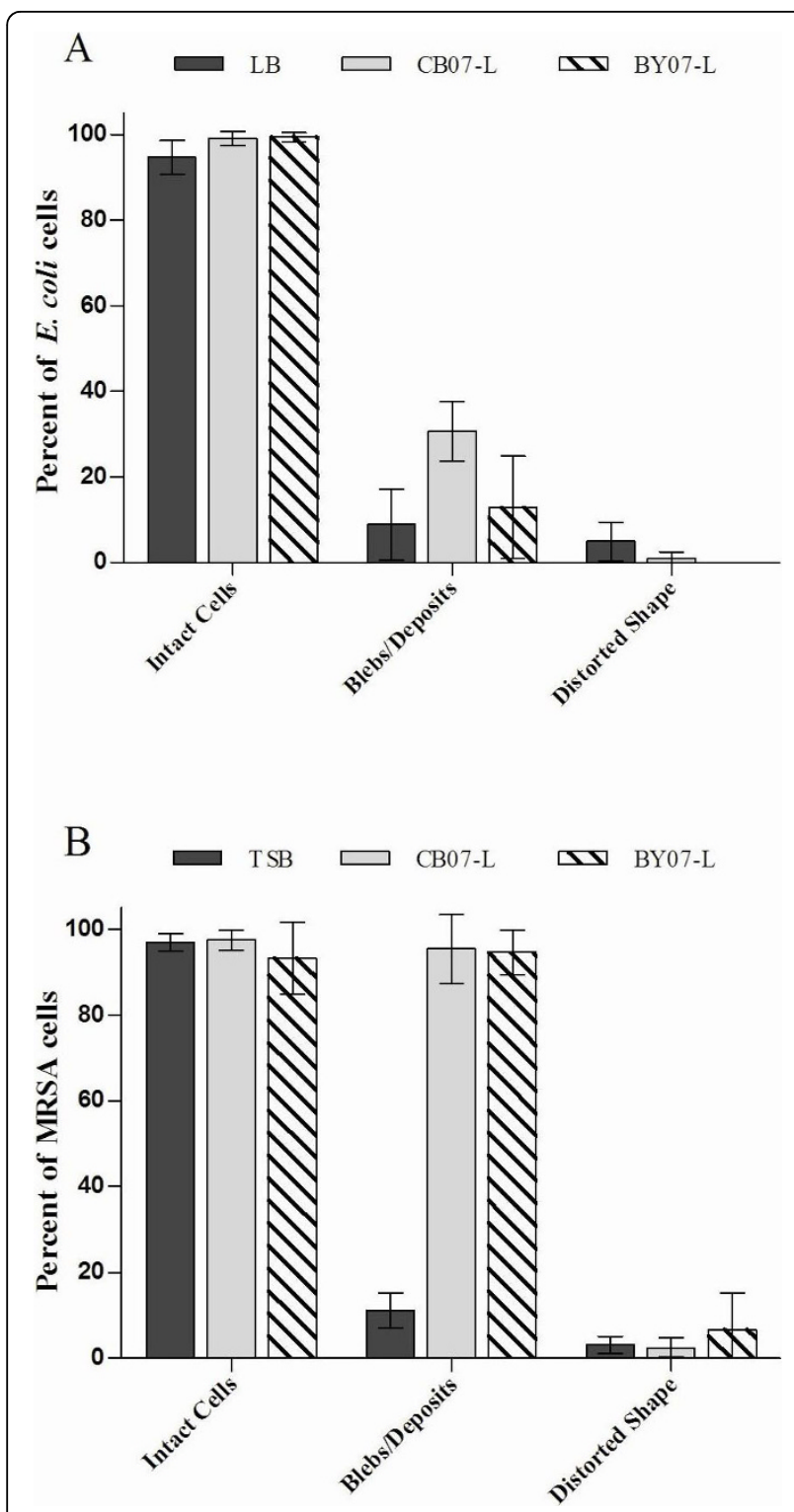

Figure 3 Frequency of characteristics observed in three independent replicates of SEM images of $E$. coli (a) and MRSA

(b). For each independent replicate, at least 200 cells were visualized and scored for the observed characteristic.

E. coli grown in LB for 24 h showed electron-dense regions (Figure 4a; white asterisk) and evidence of cytoplasmic condensation (Figure 4a). The electron-dense regions are characteristic of $E$. coli cells grown into stationary phase and are likely due to the accumulation of glycogen inclusion bodies [21]. E. coli exposed to CB07$\mathrm{L}$ and BY07-L displayed condensation of the cytoplasmic contents (Figures 4g and 4i; white arrowheads) in 97.0\% and $81.4 \%$ of cells, respectively (Figure $5 \mathrm{a}$ ). Additionally, small (diameter of $\sim 10 \mathrm{~nm}$ ) electron-dense, deposited

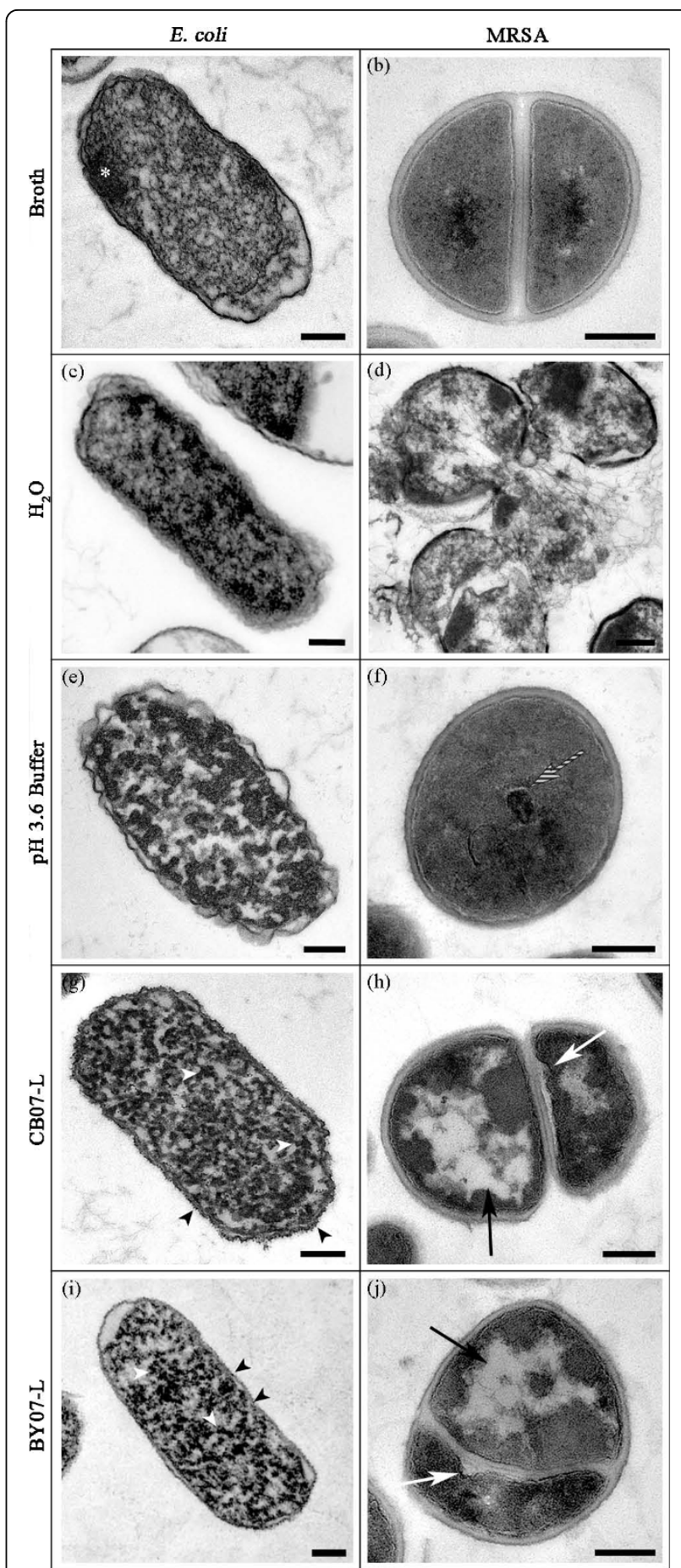

Figure 4 TEM images of $E$. coli $(a, c, e, g, i)$ and MRSA (b, d, f, $h, j)$ after 24 h incubation in broth, $\mathrm{dH}_{2} \mathrm{O}, \mathrm{pH} 3.6$ buffer, CB07L, or BY07-L. Scale bar $=200 \mathrm{~nm}$. Electron-dense region, asterisk (a); mesosome-like structure, striped arrow $(\mathrm{f})$; granules, black arrowheads $(g, i)$; cytoplasmic condensation, white arrowheads $(g, i)$; cytoplasmic disruption, black arrows (h, j); cytoplasmic membrane disruptions, white arrows (h, j). 

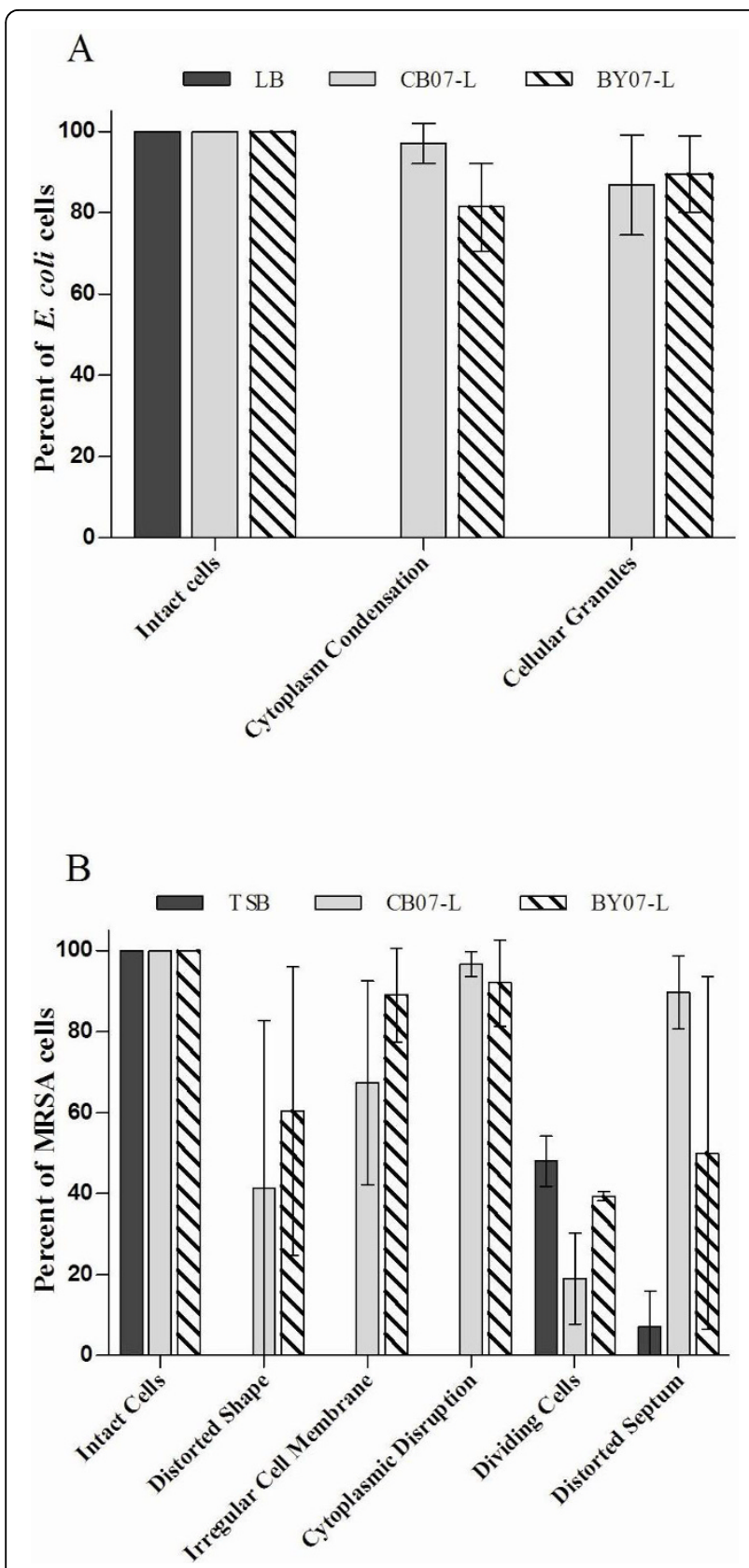

Figure 5 (a) Frequency of characteristics observed in three independent replicates of TEM images of $E$. coli (a) and MRSA

(b). For each independent replicate, at least 60 cells were visualized and scored for the observed characteristic.

or cellular-based granules bound to the cell envelope were observed (Figures $4 \mathrm{~g}$ and $4 \mathrm{i}$; black arrowheads). These granules were observed in $86.8 \%$ and $89.4 \%$ of cells exposed to CB07-L and BY07-L, respectively (Figure 5a). Feng et al. [22] reported similar electron-dense granules in TEM following E. coli and MRSA exposure to silver ions, hypothesizing that silver toxicity is due to ions entering the cells and binding to sulfhydryl groups
[22]. Because the mineral leachates were generated using water [5], both E. coli and MRSA cells were exposed to $\mathrm{dH}_{2} \mathrm{O}$ to resolve the effects of prolonged water incubations on cellular viability. Following $24 \mathrm{~h}$ exposure to $\mathrm{dH}_{2} \mathrm{O}, E$. coli viability was not significantly affected (Figures 1a and 1b). As evident in the TEM images, the effects of extended exposure of E. coli to $\mathrm{dH}_{2} \mathrm{O}$ were unremarkable, bearing similarity to the LB-exposed cells (Figures 4a and 4c). Non-uniform spacing between the E. coli cytoplasmic contents and cell envelope was observed in water-treated, broth-treated, and BY07-L- and CB07-L-treated cells (Figures 4a,c,g, and $4 \mathrm{i})$.

TEM images of MRSA confirmed that the cells remain intact following exposure to the leachates (Figures $4 \mathrm{~h}$ and $4 \mathrm{j}$ ), indicating that cell lysis is not the antibacterial mechanism of action in Gram-positive cells. Enumeration of triplicate TEM sample images verified that $100 \%$ of leachate-exposed cells remain intact (Figure 5b). Cytoplasmic disruption of MRSA (Figure $4 \mathrm{~h}$ and $4 \mathrm{j}$; black arrows) following exposure to CB07-L and BY07-L was observed in $96.7 \%$ and $92 \%$ of cells, respectively (Figure 5b). Possible disruptions in the cytoplasmic membrane (Figures $4 \mathrm{~h}$ and $4 \mathrm{j}$; white arrows) were observed in $67.3 \%$ and $89.0 \%$ of CB07-L- and BY07-Ltreated cells, respectively (Figure $5 \mathrm{~b}$ ). Cells with a distorted shape were also observed in triplicate samples of MRSA exposed to the mineral leachates. When compared to the broth control, a decreased frequency of dividing cells was observed in leachate-exposed MRSA cells (Figure 5b). Moreover, many of these leachateexposed dividing cells showed evidence of a distorted septum (Figure 5b). Following $24 \mathrm{~h}$ exposure to $\mathrm{dH}_{2} \mathrm{O}$, MRSA viability decreased by $1-\log _{10}$ unit (Figure $1 \mathrm{~b}$ ). Water-exposed MRSA cells exhibited evidence of hypoosmotic environmental stress through cell lysis, wavy cell envelope structures, and separation of cytoplasmic contents from the membrane (Figure 4d). Notably, these ultrastructural alterations were not evident in the brothexposed or leachate-exposed cells (Figures $4 \mathrm{~b}, \mathrm{~h}$, and $4 \mathrm{j}$ ), thus indicating that leachate-induced toxicity differs significantly from prolonged cell incubation in water.

CB07-L and BY07-L generate low pH environments ranging between 3.3 - 3.7 [5]. To evaluate the effects of the low $\mathrm{pH}$ on cellular ultrastructure, we exposed $E$. coli and MRSA to a $100 \mathrm{mM}$ phosphate buffer at $\mathrm{pH} 3.6$ to mimic the low $\mathrm{pH}$ environment of the leachates. After $24 \mathrm{~h}$ exposure to low $\mathrm{pH}$ buffer, E. coli viability was reduced by $3-\log _{10}$ units [5] as compared to the complete loss of viability observed after $24 \mathrm{~h}$ exposure to CB07-L and BY07-L (Figure 1a). This maintenance of viability was expected since $E$. coli exhibits an inducible acid tolerance in order to facilitate passage through the low $\mathrm{pH}$ environment of the digestive tract [23]. Low $\mathrm{pH}$ 
buffer-exposed $E$. coli displayed different patterns of cytoplasmic condensation from that of the leachateexposed cells (Figures $4 \mathrm{e}, \mathrm{g}$, and $4 \mathrm{i}$ ). In contrast to E. coli, MRSA cells exposed to the low $\mathrm{pH}$ buffer for $24 \mathrm{~h}$ were killed completely (data not shown). TEM images of low pH buffer-exposed MRSA cells revealed an even distribution of cytoplasmic contents (Figure 4f), similar to cells grown in broth (Figure 4b), demonstrating that the toxic effects induced by a low $\mathrm{pH}$ environment differ from that of the antibacterial leachates. Images of low pH buffer-exposed MRSA cells exhibited mesosome-like structures (Figure 4f; striped arrow), however, this effect was only observed in the low $\mathrm{pH}$ buffer-exposed cells and was likely a processing artifact due to exposure to the low $\mathrm{pH}$ phosphate buffer.

\section{Membrane Permeability}

While electron microscopy (EM) provides useful insight into the mechanism of action of antibacterial agents, the resulting images are observational only. Other techniques must, therefore, be used in tandem to verify the observations generated from the EM images. Accordingly, we investigated the effects of BY07-L and CB07-L on the membrane permeability of $E$. coli and MRSA by using the BacLight LIVE/DEAD bacterial viability kit. This assay uses two DNA intercalating dyes: green fluorescent SYTO9, which penetrates all membranes and red fluorescent propidium iodide (PI), which can only penetrate permeabilized membranes due to its large size and negative charge [24]. Red fluorescence is produced in the membrane-permeabilized cell by combined displacement of SYTO9 by PI and quenching of SYTO9 emission by fluorescence resonance energy transfer (FRET) [20].

CB07-L and BY07-L rapidly kill higher concentrations of $E$. coli, with bactericidal activity occurring after $1 \mathrm{~h}$ and $6 \mathrm{~h}$, respectively (Figure 6a). Because membrane permeabilization can naturally occur following cell death, these time points were used as the minimum period of time required for bactericidal activity to directly evaluate the effects of the antibacterial leachates on E. coli membrane integrity.

Following $1 \mathrm{~h}$ incubation in LB broth, E. coli viability was assessed by CFU enumeration on agar plates and resulted in an average of $10^{9} \mathrm{CFU} / \mathrm{mL}$ (Figure 6a). Given that E. coli remains viable in broth, flow cytometric analysis resulted in an average of $99.9 \%$ of cells with intact membranes (Figure 7a; Table 1). Although 1 $\mathrm{h}$ exposure to CB07-L elicited bactericidal activity (Figure 6a), flow cytometry revealed that $93.0 \%$ (average) of E. coli cells remained impermeable to PI (Figure 7g; Table 1). Similarly, flow cytometry revealed that $99.3 \%$ of E. coli cells exposed to BY07-L for $6 \mathrm{~h}$ were impermeable to PI (Figure 7i; Table 1). These data were
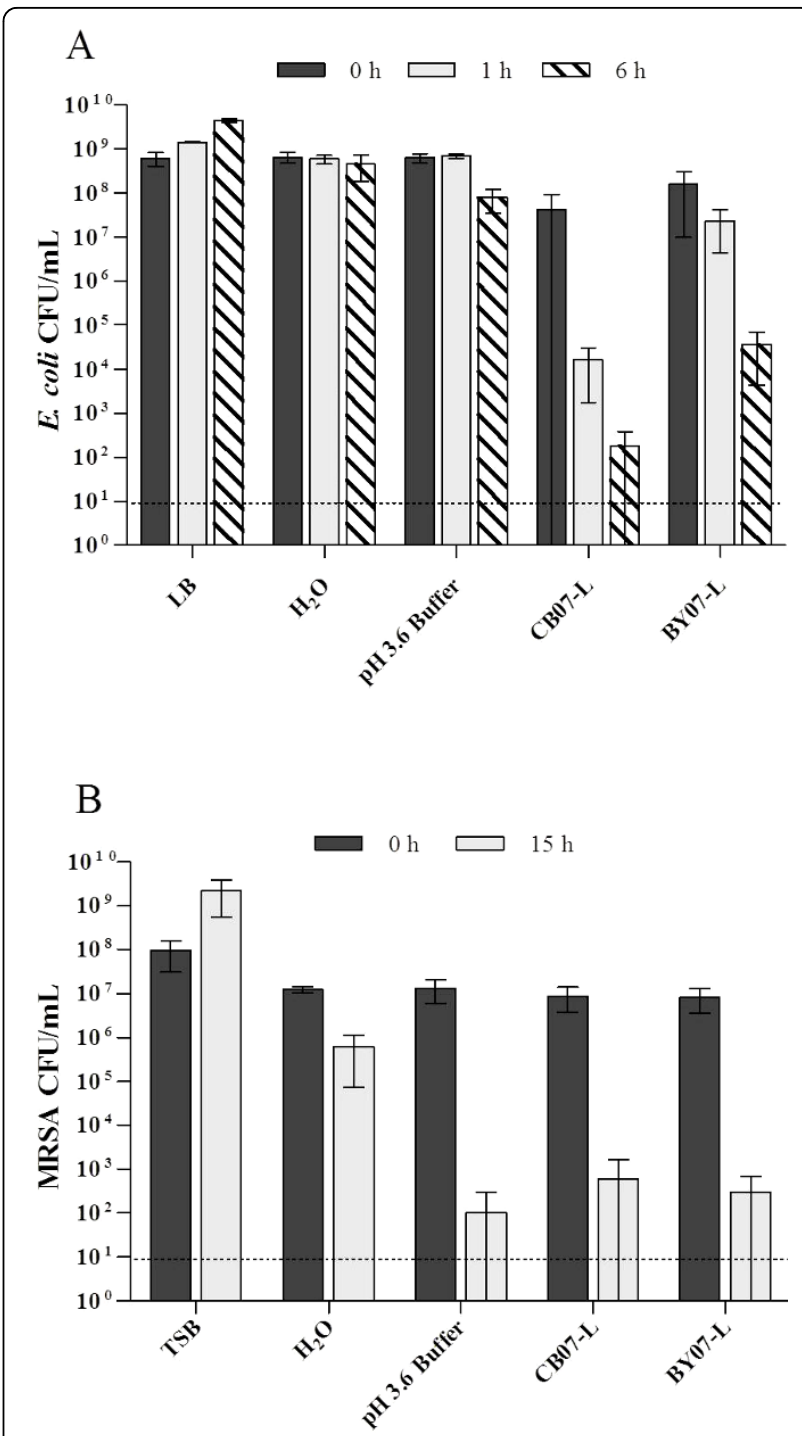

Figure 6 E. coli (a) viability determined by CFU plate counts following $1 \mathrm{~h}$ exposure to CB07-L and BY07-L. MRSA (a) viability determined by CFU plate counts following $15 \mathrm{~h}$ exposure to mineral leachates. The dotted line represents the limit of CFU detection

confirmed in triplicate flow cytometric experiments (Figure 7; Table 1) and indicate that membrane permeability does not occur in E. coli following exposure to the leachates, and thus, is not the primary mechanism of action for either of the mineral leachates (Figure 7; Table 1). E. coli cells were also exposed to a low $\mathrm{pH}$ buffer control to mimic the low $\mathrm{pH}$ environment of the leachates. Minimal membrane permeability was observed after $1 \mathrm{~h}$ exposure to low $\mathrm{pH}$ buffer (Figure $7 \mathrm{e})$, with an average of $92.3 \%$ impermeable cells detected by flow cytometry (Figure 7e; Table 1). Table 1 summarizes the two data collection methods, showing that flow cytometry data suggest an insignificant loss in 

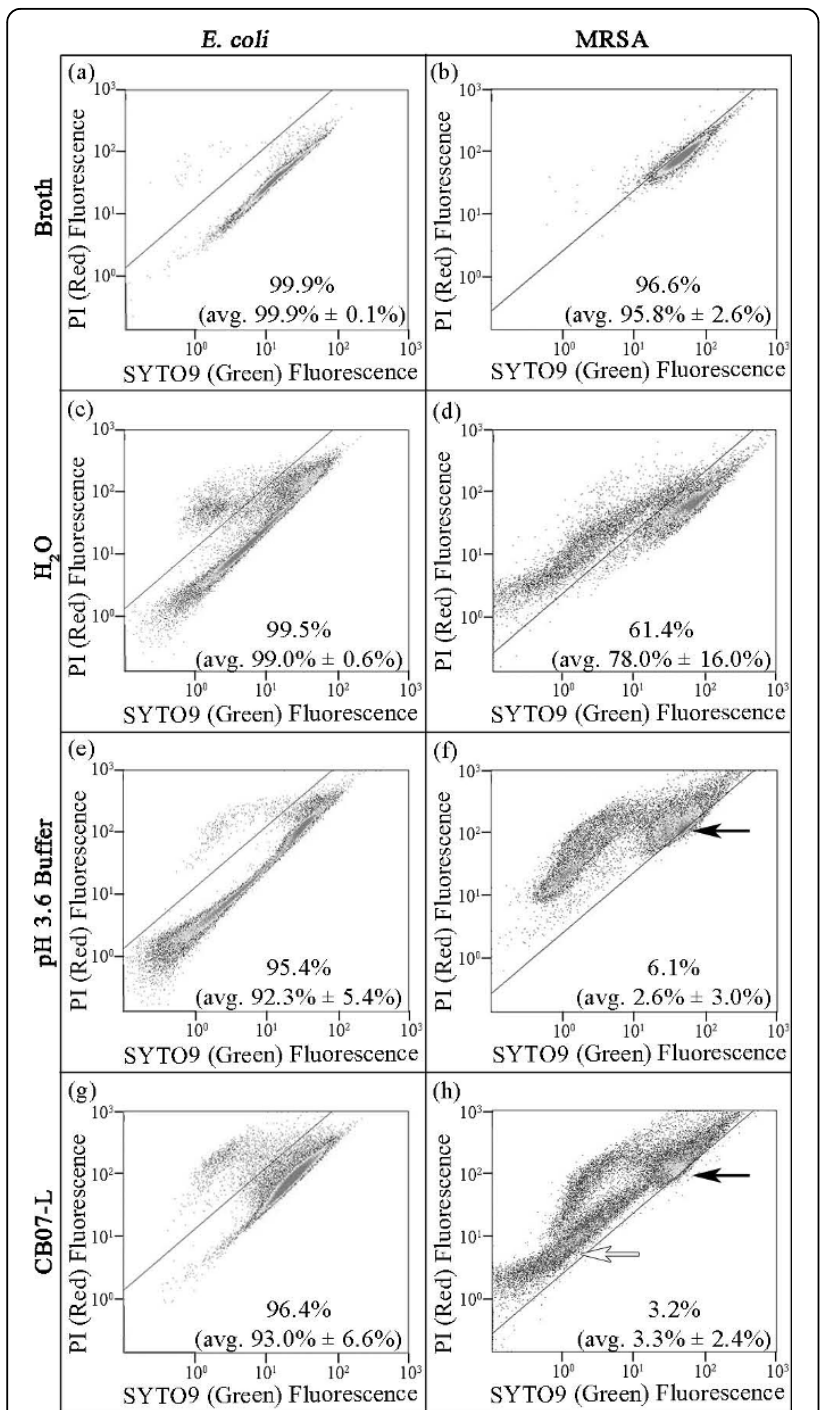
SYTO9 (Green) Fluorescence
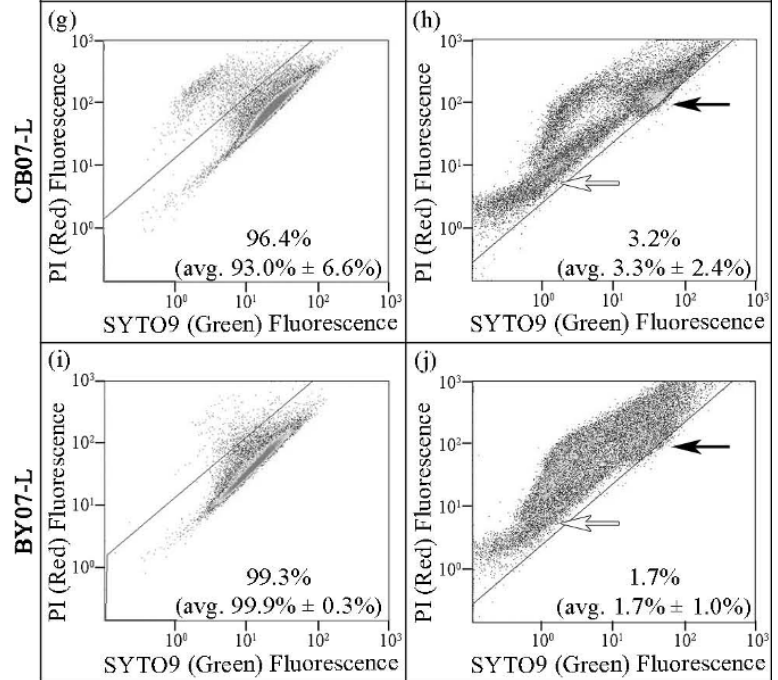

Figure 7 Flow cytometric analysis of $E$. coli $(\mathrm{a}, \mathrm{c}, \mathrm{e}, \mathrm{g}, \mathrm{i})$ and MRSA (b, d, f, h, j) after incubation in broth, $\mathrm{dH}_{2} \mathrm{O}, \mathrm{pH} 3.6$ buffer, CB07-L, or BY07-L. Two red fluorescent populations were observed with a higher fluorescence intensity (black arrow) and lower fluorescence intensity (white arrow). Flow cytometric analyses and percentages were derived from a single representative experiment. Average values from at least three independent replicate experiments are reported in parentheses. Percentages denote the number of cells that remained impermeable to PI, and therefore fluoresced green. Green fluorescence was detected on channel FL1 with a $525 \mathrm{~nm} \pm 10 \mathrm{~nm}$ bandpass filter for SYTO9; red fluorescence was detected on channel FL3 with $a \geq 620$ bandpass filter for $\mathrm{PI}$.
Table 1 Summary of $E$. coli survival and membrane permeability following incubation in LB, water, pH 3.6 phosphate buffer, and mineral leachates

\begin{tabular}{|c|c|c|c|}
\hline Treatment & $\begin{array}{l}\text { Time } \\
\text { (h) }\end{array}$ & $\begin{array}{l}\text { Flow cytometry, } \\
\text { percent intact } \\
\text { membranes } \\
(\text { avg } \pm \text { SD) }\end{array}$ & $\begin{array}{l}\text { Plate count viability, } \\
\text { CFU enumeration (\%) }\end{array}$ \\
\hline LB & 1 & $99.9(99.9 \pm 0.1)$ & $0.5-\log _{10}$ Increase $(\mathrm{n} / \mathrm{a})^{c}$ \\
\hline $\mathrm{dH}_{2} \mathrm{O}$ & 1 & $99.5(99.0 \pm 0.6)$ & $\begin{array}{c}<0.5-\log _{10} \text { Decrease } \\
(50.0)\end{array}$ \\
\hline $\begin{array}{l}\text { pH } 3.6 \\
\text { Buffer }\end{array}$ & 1 & $95.4(92.3 \pm 5.4)$ & $\begin{array}{c}<0.5-\log _{10} \text { Decrease } \\
(50.0)\end{array}$ \\
\hline CB07-L & 1 & $96.4(93.0 \pm 6.6)$ & 1.5- $\log _{10}$ Decrease (5.0) \\
\hline BY07-L & 6 & $99.3(99.9 \pm 0.3)$ & 2.5- $\log _{10}$ Decrease (0.5) \\
\hline
\end{tabular}

${ }^{a}$ Actual percentages based on 50,000 total cells analyzed by flow cytometry following exposure to experimental conditions in triplicate experiments.

${ }^{\mathrm{b}}$ Actual values presented as $\log _{10}$ comparison of viability between $0 \mathrm{~h}$ and 1 or $6 \mathrm{~h}$ exposure to experimental conditions (Figure 6a). Percent viability values were calculated based on the change in viability between $0 \mathrm{~h}$ and 1 or $6 \mathrm{~h}$ exposure for each experimental condition (Figure 6a).

c Percentage of viable cells was not applicable due to cell growth in LB over time.

viability, despite the bactericidal activity demonstrated by CFU enumeration (Figure 7; Table 1).

Based on the projected killing kinetics for MRSA, we determined $15 \mathrm{~h}$ as the minimum amount of time required for bactericidal activity for both CB07-L and BY07-L (Figure 1b). Following $15 \mathrm{~h}$ growth of MRSA in TSB, CFU plate enumeration resulted in an average of $10^{9} \mathrm{CFU} / \mathrm{mL}$ viable cells (Figure 6b). Flow cytometric analysis of these broth-exposed cells showed an average of $95.8 \%$ of cells with intact membranes (Figure 7b; Table 2). Following $15 \mathrm{~h}$ exposure of high concentrations of MRSA to both CB07-L and BY07-L, CFU plate enumeration resulted in bactericidal activity with a 99.99\% (4- $\left.\log _{10}\right)$ decrease in viability (Figure 6b). Flow cytometric analysis of these cells demonstrated that $3.2 \%$ and $1.7 \%$ of CB07-L- and BY07-L-exposed cells, respectively, have intact membranes (Figure $7 \mathrm{~h}$ and $7 \mathrm{j}$; Table 2). Table 2 summarizes the MRSA viability and membrane permeability demonstrating that these data indicate that membrane permeabilization occurred in MRSA during the $15 \mathrm{~h}$ exposure to the leachates, and thus contributed to bactericidal activity in this organism. MRSA cells were also exposed to a low $\mathrm{pH}$ phosphate buffer control to mimic the low $\mathrm{pH}$ environment of the leachates. As expected, flow cytometric analyses revealed an average of $2.6 \%$ of low $\mathrm{pH}$ buffer-exposed MRSA cells with intact membranes (Figure 7f; Table 2).

While only $2.6 \%$ of MRSA cells had intact membranes following exposure to the low $\mathrm{pH}$ buffer, comparable to 
Table 2 Summary of MRSA survival and membrane permeability following incubation in TSB, water, pH 3.6 phosphate buffer, and mineral leachates

\begin{tabular}{|c|c|c|c|}
\hline Treatment & $\begin{array}{c}\text { Time } \\
\text { (h) }\end{array}$ & $\begin{array}{l}\text { Flow cytometry, } \\
\text { percent intact } \\
\text { membranes } \\
(\text { avg } \pm \text { SD) }\end{array}$ & $\begin{array}{l}\text { CFU enumeration } \\
(\% \text { viability } \\
\text { reduction })^{b}\end{array}$ \\
\hline TSB & 15 & $96.6(95.8 \pm 2.6)$ & $2-\log _{10}$ Increase $(n / a)^{c}$ \\
\hline $\mathrm{dH}_{2} \mathrm{O}$ & 15 & $61.9(78.0 \pm 16.0)$ & $1-\log _{10}$ Decrease (90.0) \\
\hline $\begin{array}{l}\text { pH } 3.6 \\
\text { Buffer }\end{array}$ & 15 & $6.1(2.6 \pm 3.0)$ & $\begin{array}{c}5-\log _{10} \text { Decrease } \\
(99.999)\end{array}$ \\
\hline CBO7-L & 15 & $3.2(3.3 \pm 2.4)$ & $\begin{array}{c}4-\log _{10} \text { Decrease } \\
(99.99)\end{array}$ \\
\hline BY07-L & 15 & $1.7(1.7 \pm 1.0)$ & $\begin{array}{c}4.5-\log _{10} \text { Decrease } \\
(99.995)\end{array}$ \\
\hline
\end{tabular}

actual percentages based on 50,000 total cells analyzed by flow cytometry following $15 \mathrm{~h}$ exposure to experimental condition in triplicate experiments.

${ }^{\mathrm{b}}$ Actual values presented as $\log _{10}$ comparison of viability between $0 \mathrm{~h}$ and 15 $\mathrm{h}$ exposure to experimental conditions (Figure $6 \mathrm{~b}$ ). Percent viability values were calculated based on the change in viability between $0 \mathrm{~h}$ and $15 \mathrm{~h}$ exposure for each experimental condition (Figure 6b).

c Percentage of viable cells was not applicable due to cell growth in TSB over time.

the leachate-exposed cells, several remarkable differences were observed between these two populations. First, the population profile on the forward-scatter sidescatter plots (FS - SS) of MRSA cells exposed to broth medium, $\mathrm{dH}_{2} \mathrm{O}$, and the low $\mathrm{pH}$ buffer maintained a consistent shape, with $<2 \%$ of each population falling outside the gated area (Figures $8 \mathrm{~b}, \mathrm{~d}$, and $8 \mathrm{f}$ ). In contrast, a marked spread of the population on the FS - SS plot occurred following exposure to CB07-L and BY07-L, resulting in an average number of cells of $5.2 \%$ and $5.7 \%$, respectively, excluded by the gate (Figures $8 \mathrm{~h}$ and $8 j)$. These differences demonstrated that changes in cell shape and complexity occurred during exposure to the leachates, but not during exposure to TSB, $\mathrm{dH}_{2} \mathrm{O}$, or the low $\mathrm{pH}$ buffer. These flow cytometry analyses corroborate the observed changes in MRSA cell shape seen in TEM images following exposure to the leachates (Figure 4), demonstrating that the appearance of distorted cells (Figure $5 \mathrm{~b}$ ) is characteristic of leachate exposure and not due to TEM processing. Additionally, while the MRSA cells exposed to the low $\mathrm{pH}$ buffer maintained the highly red-fluorescent transitional population (Figure 7f; black arrow), it did not display the lowerintensity red-fluorescent population that was characteristic of the leachate-exposed cells (Figures $7 \mathrm{~h}$ and 7j; white arrows). These differences demonstrated that while the total number of membrane permeabilized cells was similar following MRSA exposure to the leachates and $\mathrm{pH}$ buffer, the respective differences in fluorescence

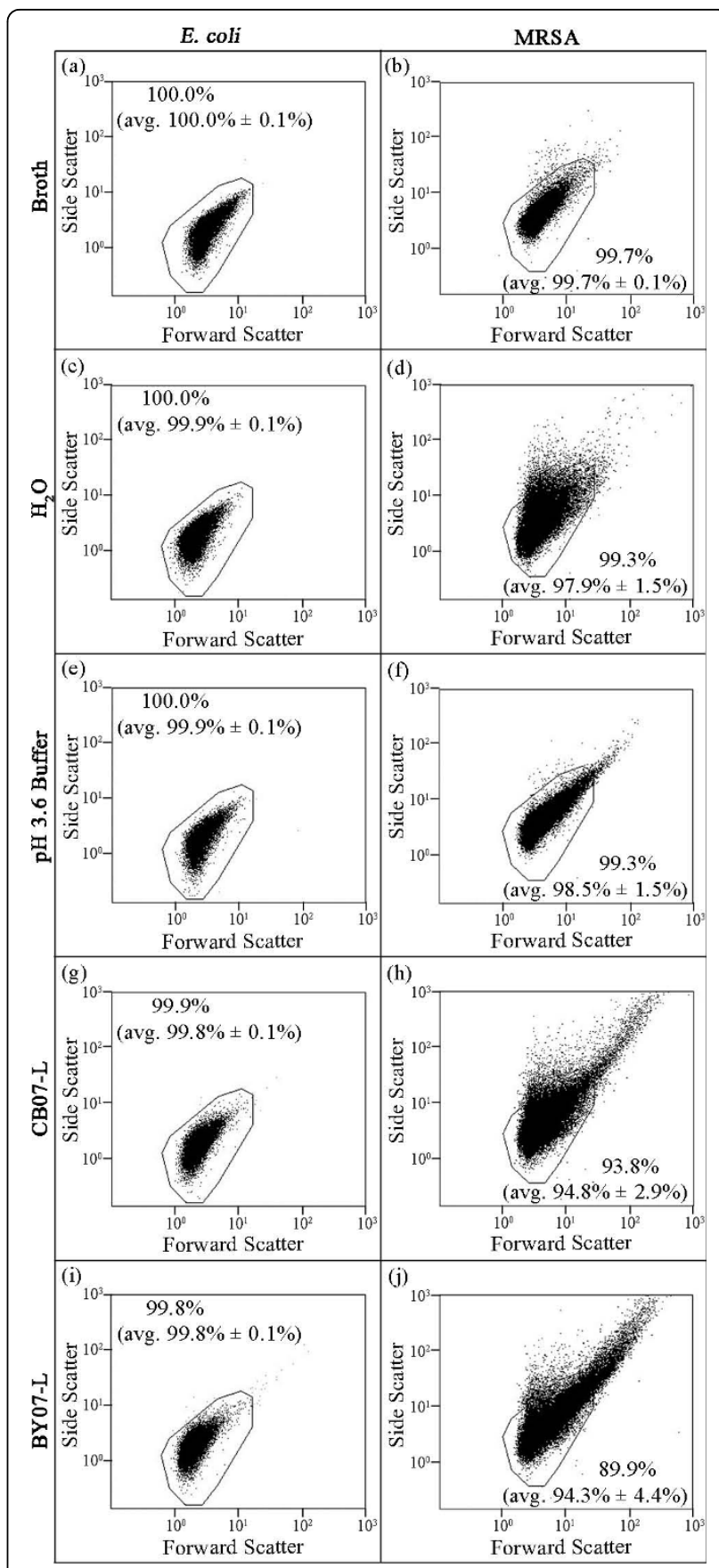

Figure 8 Forward-scatter and side-scatter dot plots of $E$. coli (a, $c, e, g, i)$ and MRSA (b, $d, f, h, j)$ determined by flow cytometry after incubation in broth, $\mathrm{dH}_{2} \mathrm{O}, \mathrm{pH} 3.6$ buffer, CB07-L, or BY07-L. Flow cytometric dot plot analyses and percentages were derived from a single representative experiment. Average values from at least three independent replicate experiments are reported in parentheses. Percentages denote the number of cells falling inside the gate.

staining patterns indicated that the mechanism of toxicity differs between the low $\mathrm{pH}$ environment alone and the leachates. No changes in size, shape, and complexity 
were observed following E. coli exposure to CB07-L and BY07-L, as demonstrated by $99.9 \%$ and $99.8 \%$ of cells, respectively, remaining inside the FS-SS gate (Figures $8 \mathrm{~g}$ and $8 \mathrm{i}$ ). Likewise, SEM and TEM images showed E. coli cells incubated in broth showed marked similarity in cell shape compared to those exposed to the antibacterial leachates (Figures 2 and 4).

\section{Discussion}

The abundance of antibiotic resistant pathogens has incrementally increased since the introduction of penicillin in the 1940s. In the United States alone, more than $70 \%$ of hospital-acquired infections are antibioticresistant, and community-acquired exposure to antibiotic-resistant pathogens is becoming increasingly prevalent $[25,26]$. This problem is further exacerbated by waning research and development of novel antibacterial agents. Historically, new antibiotics were developed by recapitulating a small set of molecular scaffolds, thus allowing opportunities for further antibiotic resistance to develop [27,28]. These alarming trends highlight the urgent need to develop novel and alternative antibacterial agents.

In the past 25 years, $\sim 70 \%$ of commercially available antibiotics have been derived from natural sources $[28,29]$. However, many unexplored natural resources remain promising for the discovery of new antibacterial agents. Clay minerals have been used historically for cosmetic purposes and to treat ailments of the digestive tract, but more recently have been investigated for their potential antibacterial properties $[2,30]$. The research presented here documents an understanding into the mechanism of action of mineral leachates, CB07-L and BY07-L, and scientifically validates the antibacterial efficacy of these clay mineral mixtures as promising new antibacterial agents. Further, an understanding of the antibacterial mechanism of action of these natural products will allow development of a chemically-derived, synthetic alternative, thus guaranteeing consistent efficacy.

Previously, we showed that the BY07 and CB07 mineral mixtures are composed of $37.3 \%$ and $21.4 \%$ smectite, respectively [5]. Smectite clays have a layered structure with an expandable interlayer and a high cation exchange capacity attributed to their overall net negative charge. In a hydrated suspension, these cations can be exchanged with ions in the external solution, provided charge balance is maintained [31]. In a low $\mathrm{pH}$ environment, the abundant protons saturate metal binding sites in the solution, maximizing the concentration of soluble metal ions. Consequently, metal ions become more bioavailable, and possibly more toxic, as the $\mathrm{pH}$ of a solution decreases [15]. Some metal ions, such as iron, copper, nickel, magnesium, manganese, and zinc, have specific biological functions as enzyme cofactors or to stabilize proteins and bacterial cell walls [15,32]. Alternatively, ions, such as aluminum, arsenic, lead, and mercury, have no biological function. Such metals can exert toxic effects by irreversibly binding sulfhydryl groups in proteins or enzyme metal binding sites [19,33]. Regardless of their function, all metals can exert toxic effects at high concentrations due to non-specific binding [15]. As a consequence, microorganisms have adapted several mechanisms, such as active transport, sequestration, and enzymatic detoxification to exclude heavy metals and regulate intracellular concentrations of essential metals [34-36]. Moreover, when metal ions are present in combination, toxicity can be magnified due to synergistic effects. For example, when lead and mercury are present together, the toxic effects are amplified 100-fold [37]. It is likely that the toxic effects of these mineral mixtures are due to the synergistic effects mediated by a combination of ions present in the solution [5]. However, further research is needed to determine which elements are mediating toxicity and their specific molecular targets.

Many groups have used EM to visualize cellular ultrastructure following exposure to silver ions $[22,38,39]$, however, minimal literature exists on the use of EM to assess antibacterial activity and ultrastructural influences of other metal ions. Following exposure to silver ions, E. coli and MRSA cells exhibit condensed DNA and electron-dense granules bound to the cell envelope $[22,38]$, in a similar manner as the CB07 and BY07 leachates (Figures 2 and 4). To our knowledge, we report the first EM ultrastructural analysis of E. coli and MRSA following exposure to antibacterial mineral leachates, demonstrating that neither $E$. coli nor MRSA cells lysed following exposure to the mineral leachates. Furthermore, changes in cell shape observed in MRSA cells following exposure to the leachates were not evident in E. coli. Condensation of the cytoplasm was observed in E. coli, and small $(\sim 10 \mathrm{~nm})$, electron-dense deposits were visualized on the surface of the cells.

CB07-L and BY07-L exhibit bactericidal activity against $E$. coli and MRSA as determined by CFU enumeration. Overall, a phenomenon occurs whereby $E$. coli is rapidly killed by CB07-L and BY07-L without permeabilization to the membrane, while MRSA is killed at a slower rate with membrane permeabilization. Tables 1 and 2 summarize the membrane permeability data determined by flow cytometry and cell viability determined by CFU enumeration. Notably, following a $6 \mathrm{~h}$ exposure to BY07-L, E. coli viability decreased by 2.5 $\log _{10}$ units (99.5\% decrease), while LIVE/DEAD staining determined that only $0.7 \%$ of the cell membranes were permeabilized. These data demonstrate the careful consideration needed when using LIVE/DEAD staining as a direct indicator of cellular viability. 
It is known that bacterial cell walls interact strongly with metal cations, maintaining control over the type and amount of ions that gain access to the cytoplasm [40]. Gram-positive cell walls specifically have been shown to have a higher charge capacity, allowing containment of a larger volume of cations [41]. For example, it has been demonstrated that Bacillus subtilis binds 28 to 33 times more $\mathrm{Cu}^{2+}$ than E. coli [41]. As a potent metal ion chelator, the thick peptidoglycan layer present in $S$. aureus likely contributes to the delayed toxicity seen with MRSA exposure to the leachates. Moreover, while these ions are trapped in the peptidoglycan, they can propagate oxidative damage to the membrane [42]. Because $E$. coli is killed without loss of membrane integrity, it is possible that membrane permeabilization observed in MRSA cells is not the principle mechanism of action, but rather a secondary consequence due to the slow passage through the thick peptidoglycan.

MRSA exposure to the leachates resulted in a distinct and reproducible fluorescence staining pattern as observed with flow cytometry. Interestingly, the dot plots of leachate-exposed MRSA cells show two redfluorescent populations. The first population moved in a distinct curve-shaped manner, transitioning from higher red fluorescence intensity to lower red fluorescence intensity (Figures 7h and 7j; black arrow). This feature is likely due to intermediate states, characterized by different concentrations of SYTO9 and PI dyes within the cells [24]. The second population, although still red, occurred at much lower fluorescence intensity (Figures $7 \mathrm{~h}$ and $7 \mathrm{j}$; white arrow). This phenomenon could possibly be due to an overall lower abundance of nucleic acids in these cells. Alternatively, due to FRET, PI fluoresces with greater intensity when in the presence of SYTO9 and at a lower intensity when present alone [20]. Therefore, the separation of these two populations may be due to a greater abundance of SYTO9 in the upper population and a decreased abundance of SYTO9 in the lower population.

Natural sources have historically played an important role in the discovery of novel antibacterial agents [29]. CB07 and BY07 mineral mixtures and their leachate derivatives could offer an additional complementary treatment option against topical bacterial infections. However, efficacy of these minerals can vary widely despite having a common source. It is therefore essential to characterize their specific antibacterial mechanism of action in order to improve quality control, guarantee consistent efficacy, and maximize their performance as an antibacterial agent.

\section{Conclusions}

In summary, these data suggest that the mineral leachate antibacterial killing activity differs for Gram-positive and
Gram-negative organisms and have guided us in our understanding of the leachate antibacterial mechanism of action. Upon antibacterial mineral leachate exposure, structural integrity is retained, however, compromised membrane integrity accounts for bactericidal activity in Gram-positive, but not in Gram-negative cells.

\section{Acknowledgements}

We thank D. Lowry and R. Roberson in the ASU School of Life Sciences for their assistance with the electron microscopy. Additionally, we gratefully acknowledge the use of facilities within the LeRoy Eyring Center for Solid State Science at Arizona State University. This research was supported by Public Health Service grants AT004690 and AT003618 awarded to S.E.H. from the National Center for Complementary and Alternative Medicine at the National Institutes of Health.

\section{Author details}

${ }^{1}$ School of Life Sciences, Arizona State University, Tempe, AZ, USA. ${ }^{2}$ The Biodesign Institute Center for Infectious Diseases and Vaccinology, Arizona State University, Tempe, AZ, USA.

\section{Authors' contributions}

CCO performed the antimicrobial susceptibility experiments, developed protocols for and performed the MRSA TEM, SEM, and BacLight LIVE/DEAD flow cytometry experiments, analyzed the MRSA TEM and SEM data, interpreted the flow cytometry data, and wrote and edited the manuscript. TMC participated in the initial design of the study, developed protocols for and performed the initial E. coli TEM and BacLight LIVE/DEAD staining experiments, and edited the manuscript. MRH performed the E. coli TEM, SEM, and BacLight LIVE/DEAD flow cytometry experiments, analyzed the $E$. coli TEM and SEM data, provided technical support for the flow cytometry experiments, interpreted the flow cytometry data, and edited the manusript. SEH conceived of the study, participated in the design and coordination of the experiments, analyzed the data, and helped to write and edit the manuscript. All authors read and approved the final manuscript.

\section{Competing interests}

The authors declare that they have no competing interests.

Received: 27 July 2010 Accepted: 16 September 2010

Published: 16 September 2010

\section{References}

1. Chastre J: Evolving problems with resistant pathogens. Clin Microbiol Infect 2008, 14(Suppl 3):3-14.

2. Carretero M: Clay minerals and their beneficial effects upon human health. A review. Appl Clay Sci 2002, 21(3-4):155-163.

3. Ziegler JL: Geophagy: a vestige of palaeonutrition. Trop Med Int Health 1997, 2(7):609-611.

4. Vermeer DE, Ferrell RE Jr: Nigerian geophagical clay: a traditional antidiarrheal pharmaceutical. Science 1985, 227(4687):634-636.

5. Cunningham TM, Koehl JL, Summers JS, Haydel SE: pH-dependent metal ion toxicity influences the antibacterial activity of two natural mineral mixtures. PLOS ONE 2010, 5(3):e9456.

6. Haydel SE, Remenih CM, Williams LB: Broad-spectrum in vitro antibacterial activities of clay minerals against antibiotic-susceptible and antibioticresistant bacterial pathogens. J Antimicrob Chemother 2008, 61(2):353-361.

7. Mpuchane SF, Ekosse GIE, Gashe BA, Morobe I, Coetzee SH: Mineralogy of southern Africa medicinal and cosmetic clays and their effects on the growth of selected test microorganisms. Fresen Environ Bull 2008, 17(5):547-557.

8. Falkinham III JO, Wall TE, Tanner JR, Tawaha K, Alali FQ, Li C, Oberlies NH: Proliferation of antibiotic-producing bacteria and concomitant antibiotic production as the basis for the antibiotic activity of Jordan's red soils. Appl Environ Microbiol 2009, 75(9):2735-2741.

9. Mpuchane SF, Ekosse Gl, Gashe BA, Morobe I, Coetzee SH: Microbiological characterisation of southern African medicinal and cosmetic clays. Int $J$ Environ Health Res 2010, 20(1):27-41. 
10. Bhattacharyya KG, Gupta SS: Adsorption of a few heavy metals on natural and modified kaolinite and montmorillonite: a review. Adv Colloid Interface Sci 2008, 140(2):114-131.

11. Velde B: Composition and mineralogy of clay minerals. In Origin and Mineralogy of Clays. Edited by: Anonymous. Berlin: Springer; 1995:8-33.

12. Beveridge TJ, Doyle RJ: Metal ions and bacteria. Wiley-Interscience 1989.

13. Lee I, Kim OK, Chang YY, Bae B, Kim HH, Baek KH: Heavy metal concentrations and enzyme activities in soil from a contaminated Korean shooting range. J Biosci Bioeng 2002, 94(5):406-411.

14. Mitra RS, Bernstein IA: Single-strand breakage in DNA of Escherichia coli exposed to $\mathrm{Cd}^{2+}$. J Bacteriol 1978, 133(1):75-80.

15. Wang LK, Hung YT, Shammas NK, eds: Handbook of Advanced Industrial and Hazardous Wastes Treatment (Advances in Industrial and Hazardous Wastes Treatment. CRC Press 2009.

16. Ercal N, Gurer-Orhan H, Aykin-Burns N: Toxic metals and oxidative stress part I: mechanisms involved in metal-induced oxidative damage. Current Topics in Medicinal Chemistry 2001, 1(6):529-539.

17. Imlay J, Chin S, Linn S: Toxic DNA damage by hydrogen peroxide through the Fenton reaction in vivo and in vitro. Science 1988, 240(4852):640-642

18. Asad NR, Leitao AC: Effects of metal ion chelators on DNA strand breaks and inactivation produced by hydrogen peroxide in Escherichia coli: detection of iron-independent lesions. J Bacteriol 1991, 173(8):2562-2568.

19. Worden CR, Kovac WK, Dorn LA, Sandrin TR: Environmental pH affects transcriptional responses to cadmium toxicity in Escherichia coli K-12 (MG1655). FEMS Microbiol Lett 2009, 293(1):58-64.

20. Stocks SM: Mechanism and use of the commercially available viability stain, BacLight. Cytometry A 2004, 61(2):189-195.

21. Makinoshima H, Aizawa S-, Hayashi H, Miki T, Nishimura A, Ishihama A Growth phase-coupled alterations in cell structure and function of Escherichia coli. J Bacteriol 2003, 185(4):1338-1345.

22. Feng QL, Wu J, Chen GQ, Cui FZ, Kim TN, Kim JO: A mechanistic study of the antibacterial effect of silver ions on Escherichia coli and Staphylococcus aureus. J Biomed Mater Res 2000, 52(4):662-668.

23. Lin J, Lee IS, Frey J, Slonczewski JL, Foster JW: Comparative analysis of extreme acid survival in Salmonella typhimurium, Shigella flexneri, and Escherichia coli. J Bacteriol 1995, 177(14):4097-4104.

24. Berney M, Hammes F, Bosshard F, Weilenmann HU, Egli T: Assessment and interpretation of bacterial viability by using the LIVE/DEAD BacLight kit in combination with flow cytometry. Appl Environ Microbiol 2007, 73(10):3283-3290.

25. Coates $A, H u$ Y, Bax R, Page $C$ : The future challenges facing the development of new antimicrobial drugs. Nat Rev Drug Discov 2002, 1(11):895-910.

26. Aiello $A E$, King NB, Foxman B: Ethical conflicts in public health research and practice: antimicrobial resistance and the ethics of drug development. Am J Public Health 2006, 96(11):1910-1914.

27. Walsh C: Where will new antibiotics come from? Nat Rev Microbiol 2003, 1(1):65-70.

28. Fischbach MA, Walsh $C T$ : Antibiotics for emerging pathogens. Science 2009, 325(5944):1089-1093.

29. Newman DJ, Cragg GM: Natural products as sources of new drugs over the last 25 years? J Nat Prod 2007, 70(3):461-477.

30. World Health Organization: Draft report of the 5th WHO advisory group meeting on Buruli ulcer. 2002.

31. Wypych F: Chemical modification of clay surfaces. In Encyclopedia of Surface and Colloid Science. Edited by: Hubbard A. New York: CRC Press; 2002:995-1010.

32. Gadd GM: Metals and microorganisms: A problem of definition. FEMS Microbiol Lett 1992, 100(1-3):197-203.

33. Nies DH: Microbial heavy-metal resistance. Appl Microbiol Biotechnol 1999, 51(6):730-750.

34. Cohen I, Bitan R, Nitzan Y: The effect of zinc and cadmium ions on Escherichia coli B. Microbios 1991, 68(276-277):157-168.

35. Nies $\mathrm{DH}$, Silver $\mathrm{S}$ : Ion efflux systems involved in bacterial metal resistances. J Ind Microbiol Biotechnol 2005, 14(2):186-199.

36. Mejáre $M$, Bülow L: Metal-binding proteins and peptides in bioremediation and phytoremediation of heavy metals. Trends Biotechnol 2001, 19(2):67-73.
37. Schubert J, Riley EJ, Tyler SA: Combined effects in toxicology-a rapid systematic testing procedure: Cadmium, mercury, and lead. J Toxicol Environ Health A 1978, 4(5):763-776.

38. Jung WK, Koo HC, Kim KW, Shin S, Kim SH, Park YH: antibacterial activity and mechanism of action of the silver ion in Staphylococcus aureus and Escherichia coli. Appl Environ Microbiol 2008, 74(7):2171-2178.

39. Yamanaka M, Hara K, Kudo J: Bactericidal actions of a silver-ion solution on Escherichia coli, studied by energy-filtering transmission electron microscopy and proteomic analysis. Appl Environ Microbiol 2005, 71(11):7589-7593.

40. Beveridge TJ, Koval SF: Binding of metals to cell envelopes of Escherichia coli K-12. Appl Environ Microbiol 1981, 42(2):325-335.

41. Mullen MD, Wolf DC, Ferris FG, Beveridge TJ, Flemming CA, Bailey GW: Bacterial sorption of heavy metals. Appl Environ Microbiol 1989, 55(12):3143-3149.

42. Gadd GM: Advances in Applied Microbiology. Academic Press 2001.

doi:10.1186/1476-0711-9-26

Cite this article as: Otto et al:: Effects of antibacterial mineral leachates on the cellular ultrastructure, morphology, and membrane integrity of Escherichia coli and methicillin-resistant Staphylococcus aureus. Annals of Clinical Microbiology and Antimicrobials 2010 9:26.

\section{Submit your next manuscript to BioMed Central and take full advantage of:}

- Convenient online submission

- Thorough peer review

- No space constraints or color figure charges

- Immediate publication on acceptance

- Inclusion in PubMed, CAS, Scopus and Google Scholar

- Research which is freely available for redistribution

Submit your manuscript at www.biomedcentral.com/submit
Biomed Central 